\title{
One-dose ChAdOx1 nCoV-19 Vaccine Effectiveness Against Symptomatic COVID-19 in a vulnerable community in Rio de Janeiro, Brazil: test-negative design study
}

Running title: Vaccine effectiness of ChAdOx1 in a vulnerable community

Otavio T Ranzani ${ }^{1,2}$, Amanda A B Silva ${ }^{3}$, Igor T Peres ${ }^{3}$, Bianca B P Antunes ${ }^{3}$, Thiago W Gonzagada-Silva ${ }^{4}$, Daniel R Soranz ${ }^{4,5}$, José Cerbino-Neto ${ }^{4,6}$, Silvio Hamacher ${ }^{3}$, Fernando A Bozza ${ }^{6,7}$

1 Barcelona Institute for Global Health, ISGlobal, Universitat Pompeu Fabra, CIBER Epidemiología y Salud Pública, Barcelona, Spain

2 Pulmonary Division, Heart Institute (InCor), Hospital das Clinicas HCFMUSP, Faculdade de Medicina, Universidade de Sao Paulo, Brazil

3 Department of Industrial Engineering (DEI) and Tecgraf Institute, Pontifical Catholic University of Rio de Janeiro (PUC-Rio), Rio de Janeiro, Brazil

4 Rio de Janeiro Municipal Health Department, Rio de Janeiro, Brazil

5 Public Health National School, Oswaldo Cruz Foundation (INI-FIOCRUZ), Rio de Janeiro, Brazil

6 National Institute of Infectious Disease Evandro Chagas, Oswaldo Cruz Foundation (INIFIOCRUZ), Rio de Janeiro, Brazil,

7 D’Or Institute for Research and Education (IDOR), Rio de Janeiro, Brazil

Correspondence to: Otavio T. Ranzani, MD, PhD, Barcelona Institute for Global Health, ISGlobal, Campus Mar, Barcelona Biomedical Research Park, Doctor Aguaider 88, Barcelona, Spain 08003 (otavio.ranzani@isglobal.org) or Fernando A Bozza MD, PhD, Laboratório de Pesquisa Clínica em Medicina Intensiva, Instituto Nacional de Infectologia Evandro Chagas, Fundação Oswaldo Cruz, Rio De Janeiro 21045-900, Brazil (fernando.bozza@ini.fiocruz.br)

Key words: COVID-19; vaccine; Brazil; vulnerable community; test-negative 
medRxiv preprint doi: https://doi.org/10.1101/2021.10.16.21265095; this version posted October 20, 2021. The copyright holder for this preprint (which was not certified by peer review) is the author/funder, who has granted medRxiv a license to display the preprint in perpetuity. It is made available under a CC-BY-NC-ND 4.0 International license.

ABSTRACT (50/50 words)

We conducted a test-negative study design at the community "Complexo da Maré", the largest group of favelas in Rio de Janeiro, Brazil, when Gamma and Delta were the predominant variants circulating. We estimated $42.4 \%(95 \% \mathrm{Cl}, 24.6,56.0)$ protection against symptomatic COVID-19 after 21 days of one dose of ChAdOx1. 
INTRODUCTION $(1447 / 1500)$

Several studies have reported the disproportionate impact COVID-19 is having on vulnerable communities [1-3]. This impact is due to the perpetuated social, economic and health inequities. Recently, inequity in access to vaccines has become a global issue [4]. Large populations in low- and middle-income countries (LMIC) live in slums or favelas, densely populated urban areas with deteriorated or incomplete infrastructure, but with a high risk of infectious disease transmission, limited access to health services or even vaccination.

Although the effectiveness of COVID-19 vaccines has been addressed in several articles from high income countries, studies that estimate vaccine effectiveness in neighborhoods such as favelas are lacking. We estimated the vaccine effectiveness of one dose of ChAdOx1 nCoV-19 (AstraZeneca/Oxford, hereafter ChAdOx1) vaccine against symptomatic COVID-19 using a test-negative design in the population of a large vulnerable community (“Complexo da Maré") in Rio de Janeiro, Brazil.

\section{METHODS}

"Complexo da Maré" is the largest group of favelas in Rio de Janeiro's city, composed by 16 favelas with 140,000 residents [5], $54 \%$ of the population aged $\leq 30$ years, and low HDI (0.686, 123rd out of Rio's 126 neighbourhoods) in 2010 [6]. From the beginning of the pandemic until 14 September 2021, the region presented high rates of positive cases $(6,416 / 100,000)$ and deaths $(267 / 100,000)$ [7]. Since July 2020 , a community broad testing strategy became available at the "Complexo da Maré" after an effort of civil society, NGOs and local community [8]. The testing was free of any charge and available on tents located in three different regions in Maré. There have been 193 RT-PCR tests per 1,000 inhabitants since the beginning of the campaign. During the study period, Gamma was the prevalent Variant of Concern in Rio de 
medRxiv preprint doi: https://doi.org/10.1101/2021.10.16.21265095; this version posted October 20, 2021. The copyright holder for this preprint (which was not certified by peer review) is the author/funder, who has granted medRxiv a license to display the preprint in perpetuity.

It is made available under a CC-BY-NC-ND 4.0 International license .

Janeiro and Delta became dominant after July 2021 [9]. This study was approved by the National Research Ethics Committee (IRB/CONEP) (CAAE - 49726921.6.0000.5248).

The COVID-19 vaccination campaign for Rio's general population started on January 17, 2021, according to an age-based strategy. The vaccination campaign in "Complexo da Maré" initially followed the Rio's city strategy, and by the end of July 2021 , only $38 \%$ of Maré residents had received a first dose $(53,084)$ and $13 \%$ a second or single dose $(19,203)$ of COVID-19 vaccines. Then, Maré received a mass vaccination campaign, which applied about 36,000 first doses of ChAdOx1, over four days (July 29-August 1 ), achieving a coverage of about $85 \%$ of the adult population with at least 1 dose. Our analysis encompasses the period between Jan 17 , 2021, and Sept 14, 2021. During this period, 136,026 doses $(97,200$ first doses and 38,826 second or single doses) were administered, being 83,762 doses $(64,352$ first doses and 19,410 second doses) of ChAdOx1. We did not analyze other vaccine platforms because of the small coverage proportion in the area.

We used a test-negative design to estimate the vaccine effectiveness of ChAdOx1 first dose, against symptomatic COVID-19. We linked the community-program testing database with the vaccination campaign database using a unique identifier (CPF, Cadastro de Pessoas Físicas). Overall, we followed the methodology reported elsewhere [10]. The description of inclusion/exclusion criteria is shown in eFigure 1. Briefly, we selected all RT-PCR (positive and negative tests) from symptomatic individuals, defined as presenting at least one symptom, from RT-PCRs sampled within 10 days of symptoms onset [11]. We excluded individuals with a previous positive RT-PCR, and those with a negative and subsequent positive test in the following 14 days. In a secondary analysis, we also included RT-PCR tests from asymptomatic individuals.

We estimated the vaccine effectiveness as 1-OR from logistic regression models. Our primary outcome was effectiveness against symptomatic COVID-19 after 21 days of the first 
dose of ChAdOx1. RT-PCR tests sampled after the second dose were excluded. We adjusted by time of epidemic using a restricted cubic spline on day of the year, and subsequently adjusted by age (restricted cubic spline), sex, self-reported race, Maré residence (three different regions - north, center and south), occupation, whether the RT-PCR was from routine testing or spontaneous walking, and for six chronic comorbidities. We evaluated the interaction between effectiveness and the age groups divided by the median of the symptomatic population ( $\leq 35$ years; >35 years). We conducted four sensitivity analyses: 1) Excluding test-negative cases that reported taste/smell alterations [11]; 2) Expanding the time groups after the first dose until 56 days; 3) Analyzing symptomatic and asymptomatic cases, and 4) Analyzing only asymptomatic cases. We have missing data only for self-reported race $(15 \%)$ and chronic comorbidities $(<1 \%)$. We generated 20 multiple imputed datasets using the standard procedure for multiple imputation using chained equation. We summarized the estimates and generated $95 \%$ confidence intervals using the Rubin's rules. All analyses were conducted in R statistical software version 4.0.3.

\section{RESULTS}

Between Jan 17, 2021, and Sept 14, 2021, there were 15,771 RT-PCR tests in the community. After the inclusion/exclusion criteria (e-Figure 1), we analyzed 9,197 RT-PCR tests for the testnegative design. Overall, $36 \%$ of tests were from asymptomatic individuals. The test positivity was $20.6 \%$ (1211/5890) for symptomatic and 5.9\% (195/3307) for asymptomatic cases (eFigure 2 and 3).

The general characteristics of the analyzed population for symptomatic cases is shown in eTable 1 . The mean age was $38 \pm 13$ years, $65 \%$ of females and $41 \%$ of Brown/Pardo selfreported color. There were small proportion of individuals with chronic comorbidities, being most 
common obesity (9\%) followed by cardiovascular disease (7\%). Two-hundred and ten (3.6\%) of individuals were healthcare workers. The median time between vaccination and RT-PCR testing among vaccinated was 36 [p25-p75: 20-60] days. The characteristics of the sample for asymptomatic and symptomatic and asymptomatic cases are shown in eTable 2 and eTable 3.

Vaccine effectiveness of one dose of ChAdOx1 is shown in Table 1. Fully adjusted vaccine effectiveness against symptomatic COVID-19 after 21 days of one dose was $42.4 \%$ (95\% Cl, 24.6\%, 56.0\%). The period 0-13 (bias-indicator) showed no indication of bias. For the sensitivity analysis for the primary outcome, excluding negative tests from individuals with taste/smell symptoms $(n=4,951)$, the adjusted VE against symptomatic COVID-19 was $46.5 \%$ (95\% Cl, 29.4\%, 59.5\%) after 21 days (eTable 4$).$

There was an interaction for age groups, with the young group (age $\leq 35$ years) showing high effectiveness $\left(57.5 \% ; 95 \% \mathrm{Cl}, 33.7 \%, 72.7 \% ; \mathrm{P}_{\text {interaction }}=0.04\right)$. The adjusted VE increased for subsequent days after the first dose, except for $>56$ days. The vaccine effectiveness when considering those symptomatic and asymptomatic together $(40.7 \% ; 95 \% \mathrm{Cl}, 24.1 \%, 53.8 \%)$ was comparable to the main analysis. The vaccine effectiveness only among asymptomatic tests was $29.8 \%(95 \% \mathrm{Cl},-44.2 \%, 65.8 \%$, eTable 5$)$.

\section{DISCUSSION}

We observed a vaccine effectiveness of $42 \%$ against symptomatic COVID-19 after a single dose of ChAdOx1 in a vulnerable population in Rio de Janeiro, Brazil, in a period of mixed Gamma and Delta dominance.

Our estimate is in accordance with previous evaluations for vaccine effectiveness of the first dose of ChAdOx1 in the context of Gamma or Delta $[12,13]$. We observed the vaccine effectiveness increased up to $58.6 \%(28.0,76.2)$ during $42-55$ days of the first dose, which has 
been reported [12] and a decrease afterwards. We can hypothesize that this decrease might occur because of some factors, such limited power to evaluate vaccine effectiveness at this time window and increase on the dominance of Delta.

There is limited evidence for vaccine effectiveness against infection. We aimed to evaluate it combining asymptomatic cases in the estimates. The estimates are comparable to the protection against symptomatic cases, as previously reported [13]. However, the limited sample size resulting in low number of events among asymptomatic cases, shifts the estimate of the combined analysis towards symptomatic cases. Our analyses only with asymptomatic cases, although with large imprecision, shows a potential for effectiveness against asymptomatic infection. A detailed analysis on symptoms, such as a follow-up on those asymptomatic at RT-PCR collection or active surveys regarding symptoms, could help on understanding vaccine effectiveness against infection.

Our study has some limitations. First, we could not evaluate second dose effectiveness and waning because of the vaccination campaign and enough follow-up. Second, data on genome sequencing from all test-positives was not available. However, our study analyzed data in a period of high transmission rates of the Gamma and Delta variants in the community. Third, we could not evaluate the vaccine effectiveness for preventing COVID-19 hospitalizations or severe outcomes. Finally, although we excluded previous confirmed infections, it is expected that the community has a high attack rate and so the unvaccinated could have an unmeasured protection level, underestimating the vaccine effectiveness.

One-dose of ChAdOx1 was effective on reducing symptomatic COVID-19 in using data from a community surveillance program, where there was a broad testing strategy without any cost to an overall young vulnerable population in a group of favelas in Brazil. 


\section{Acknowledgments.}

We thank the Redes da Mare for all support and the efficient strategies on community engagement and communication during the pandemic and the Unidade de Apoio ao Diagnóstico da Covid-19 (UNADIG-FIOCRUZ) for the support on the testing diagnosis. OTR acknowledges support from the Spanish Ministry of Science and Innovation through the Centro de Excelencia Severo Ochoa 2019-2023 Program and from the Generalitat de Catalunya through the CERCA Program. We thank the Center for Healthcare Operations and Intelligence (NOIS) research group for their discussions and collaborative production of scientific analyses of the COVID-19 pandemic in Brazil.

\section{Financial support.}

This work is part of the Grand Challenges ICODA pilot initiative, delivered by Health Data Research UK and funded by the Bill \& Melinda Gates Foundation and the Minderoo Foundation. This study was also supported by the National Council for Scientific and Technological Development (CNPq), the Coordinating Agency for Advanced Training of Graduate Personnel (CAPES; finance code 001), Carlos Chagas Filho Foundation for Research Support of the State of Rio de Janeiro (FAPERJ), and the Pontifical Catholic University of Rio de Janeiro. OTR is funded by a Sara Borrell grant from the Instituto de Salud Carlos III (CD19/00110).

\section{Potential conflicts of interest.}

All authors reported no conflicts. All authors carried out the research independently of the funding bodies. The findings and conclusions of this Article reflect the opinions of the authors and not those of the funding bodies or other affiliations of the authors. 
medRxiv preprint doi: https://doi.org/10.1101/2021.10.16.21265095; this version posted October 20, 2021. The copyright holder for this preprint (which was not certified by peer review) is the author/funder, who has granted medRxiv a license to display the preprint in perpetuity.

It is made available under a CC-BY-NC-ND 4.0 International license .

\section{REFERENCES}

1. Peres IT, Bastos LSL, Gelli JGM, et al. Sociodemographic factors associated with COVID19 in-hospital mortality in Brazil. Public Health 2021; 192:15-20.

2. Karmakar M, Lantz PM, Tipirneni R. Association of Social and Demographic Factors With COVID-19 Incidence and Death Rates in the US. JAMA Network Open 2021; 4.

3. Wollenstein-Betech SI, Silva AAB, Fleck JL, Cassandras CG, Ch PaschalidisID I. Physiological and socioeconomic characteristics predict COVID-19 mortality and resource utilization in Brazil. Plos One 2020;

4. Hassan F, Yamey G, Abbasi K. Profiteering from vaccine inequity: a crime against humanity? BMJ 2021; 374.

5. Redes da Maré. Censo populacional da Maré. 2019;

6. Atlas Brasil | Bases do Censo e das UDHs por Regiões Metropolitanas. Available at: http://www.atlasbrasil.org.br/acervo/biblioteca. Accessed 8 July 2021.

7. CEP dos casos confirmados de COVID-19 no município do Rio de Janeiro | Data Rio. Available at: https://www.data.rio/datasets/PCRJ::cep-dos-casos-confirmados-de-covid-19no-município-do-rio-de-janeiro-1/about. Accessed 20 September 2021.

8. Dantas LF, Peres IT, Bastos LSL, et al. App-based symptom tracking to optimize SARSCoV-2 testing strategy using machine learning. PLOS ONE 2021; 16:e0248920.

9. Rede Fluminense de ômicas na COVID-19. Available at: http://www.coronaomica.rj.Incc.br/\#/. Accessed 13 October 2021.

10. Ranzani OT, Hitchings MDT, Dorion M, et al. Effectiveness of the CoronaVac vaccine in older adults during a gamma variant associated epidemic of covid-19 in Brazil: test negative case-control study. BMJ 2021; 374.

11. MK P, I B, JS B, et al. Evaluation of post-introduction COVID-19 vaccine effectiveness: Summary of interim guidance of the World Health Organization. Vaccine 2021; 39:40134024.

12. Hitchings MDT, Ranzani OT, Dorion M, et al. Effectiveness of the ChAdOx1 vaccine in the elderly during SARS-CoV-2 Gamma variant transmission in Brazil. 2021: 2021.07.19.21260802. Available at: https://www.medrxiv.org/content/10.1101/2021.07.19.21260802v1. Accessed 15 October 2021.

13. Pouwels KB, Pritchard E, Matthews PC, et al. Impact of Delta on viral burden and vaccine effectiveness against new SARS-CoV-2 infections in the UK. 2021: 2021.08.18.21262237. Available at: https://www.medrxiv.org/content/10.1101/2021.08.18.21262237v1. Accessed 15 October 2021. 
Table 1. Vaccine effectiveness of the first dose of ChAdOx1

\begin{tabular}{|c|c|c|c|c|}
\hline & \multicolumn{2}{|c|}{$\begin{array}{c}\text { Symptomatic } \\
\text { ( } n=5,890 \text { tests) }\end{array}$} & \multicolumn{2}{|c|}{$\begin{array}{c}\text { Symptomatic + Asymptomatic } \\
\text { (n=9,197 tests) }\end{array}$} \\
\hline & OR $(95 \% \mathrm{Cl})$ & VE (95\% Cl) & OR $(95 \% \mathrm{Cl})$ & VE (95\% Cl) \\
\hline \multicolumn{5}{|l|}{ Adjusted by time of pandemic* } \\
\hline $0-13$ days after first dose & $0.84(0.55,1.29)$ & $15.6 \%(-28.9,44.8)$ & $0.74(0.51,1.07)$ & $25.6 \%(-7.4,48.5)$ \\
\hline 14-21 days after first dose & $1.03(0.66,1.60)$ & $-2.6 \%(-59.7,34.0)$ & $0.90(0.61,1.34)$ & $9.5 \%(-33.5,38.7)$ \\
\hline Unvaccinated & Reference & Reference & Reference & Reference \\
\hline 0 -13 days after first dose & $0.89(0.58,1.36)$ & $11.4 \%(-36.1,42.3)$ & $0.91(0.62,1.34)$ & $8.8 \%(-33.6,37.8)$ \\
\hline 14-21 days after first dose & $1.00(0.64,1.57)$ & $-0.2 \%(-57.2,36.1)$ & $1.05(0.70,1.57)$ & $-4.5 \%(-56.6,30.2)$ \\
\hline$>21$ days after first dose & $0.58(0.44,0.75)$ & $42.4 \%(24.6,56.0)$ & $0.59(0.46,0.76)$ & $40.7 \%(24.1,53.8)$ \\
\hline \multicolumn{5}{|c|}{ Effect modification by age (fully adjusted) } \\
\hline $0-13$ days after first dose & $0.89(0.58,1.37)$ & $11.1 \%(-36.6,42.1)$ & $0.91(0.62,1.34)$ & $8.5 \%(-34.1,37.6)$ \\
\hline 14-27 days after first dose & $0.87(0.61,1.24)$ & $12.7 \%(-24.4,38.8)$ & $0.89(0.64,1.23)$ & $11.2 \%(-22.7,35.7)$ \\
\hline 28-41 days after first dose & $0.55(0.36,0.84)$ & $45.2 \%(16.2,64.1)$ & $0.55(0.37,0.82)$ & $45.0 \%(17.7,63.2)$ \\
\hline 42-55 days after first dose & $0.41(0.24,0.72)$ & $58.6 \%(28.0,76.2)$ & $0.47(0.28,0.77)$ & $53.5 \%(23.0,71.9)$ \\
\hline$>56$ days after first dose & $0.63(0.44,0.92)$ & $36.7 \%(7.9,56.4)$ & $0.65(0.46,0.92)$ & $35.0 \%(8.3,53.8)$ \\
\hline
\end{tabular}




\section{Supplementary Data}

One-dose ChAdOx1 nCoV-19 Vaccine Effectiveness Against Symptomatic COVID19 in a vulnerable community in Rio de Janeiro, Brazil: test-negative design study

\section{Table of Contents}

eFigure 1. Flowchart

eFigure 2. RT-PCR tests and results during the study period stratified by presence of symptoms

eFigure3. Test positivity proportion during the study period stratified by presence of symptoms

eFigure 4. First doses of AstraZeneca vaccine during the vaccination campaign in the "Complexo da Maré".

eTable 1 - Characteristics for the symptomatic cases ....................................................6 6

eTable 2. Characteristics for the asymptomatic cases .................................................. 7

eTable 3 - Characteristics for symptomatic and asymptomatic cases ................................8 8

eTable 4. Vaccine effectiveness against symptomatic COVID-19 (sensitivity analysis excluding test-negatives with taste/smell symptoms) ..............................................9

eTable 5. Vaccine effectiveness against asymptomatic COVID-19 (sensitivity analysis) .... 10 
medRxiv preprint doi: https://doi.org/10.1101/2021.10.16.21265095; this version posted October 20, 2021. The copyright holder for this preprint (which was not certified by peer review) is the author/funder, who has granted medRxiv a license to display the preprint in perpetuity. It is made available under a CC-BY-NC-ND 4.0 International license.

\section{eFigure 1. Flowchart}

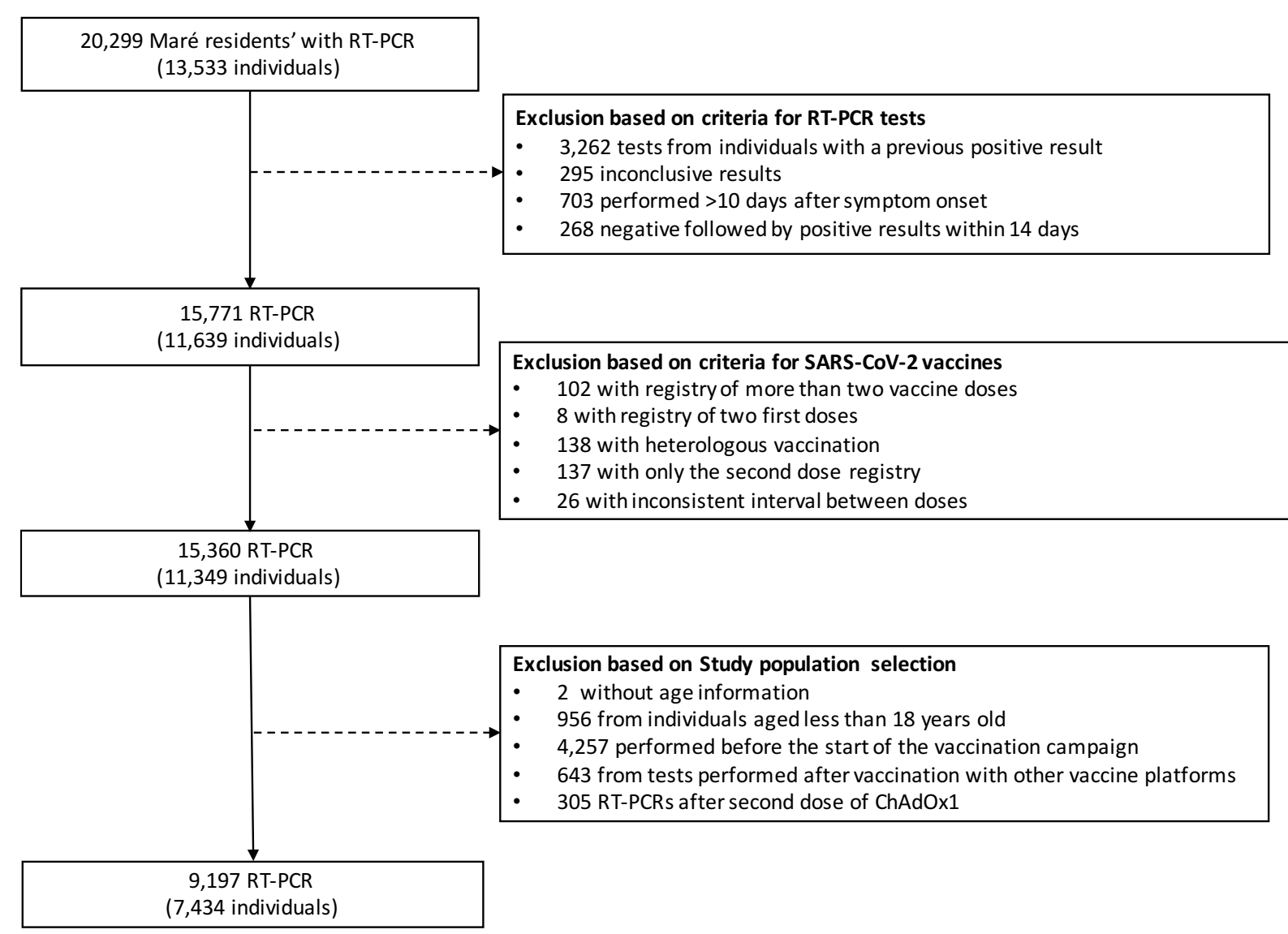


efigure 2. RT-PCR tests and results during the study period stratified by presence of symptoms

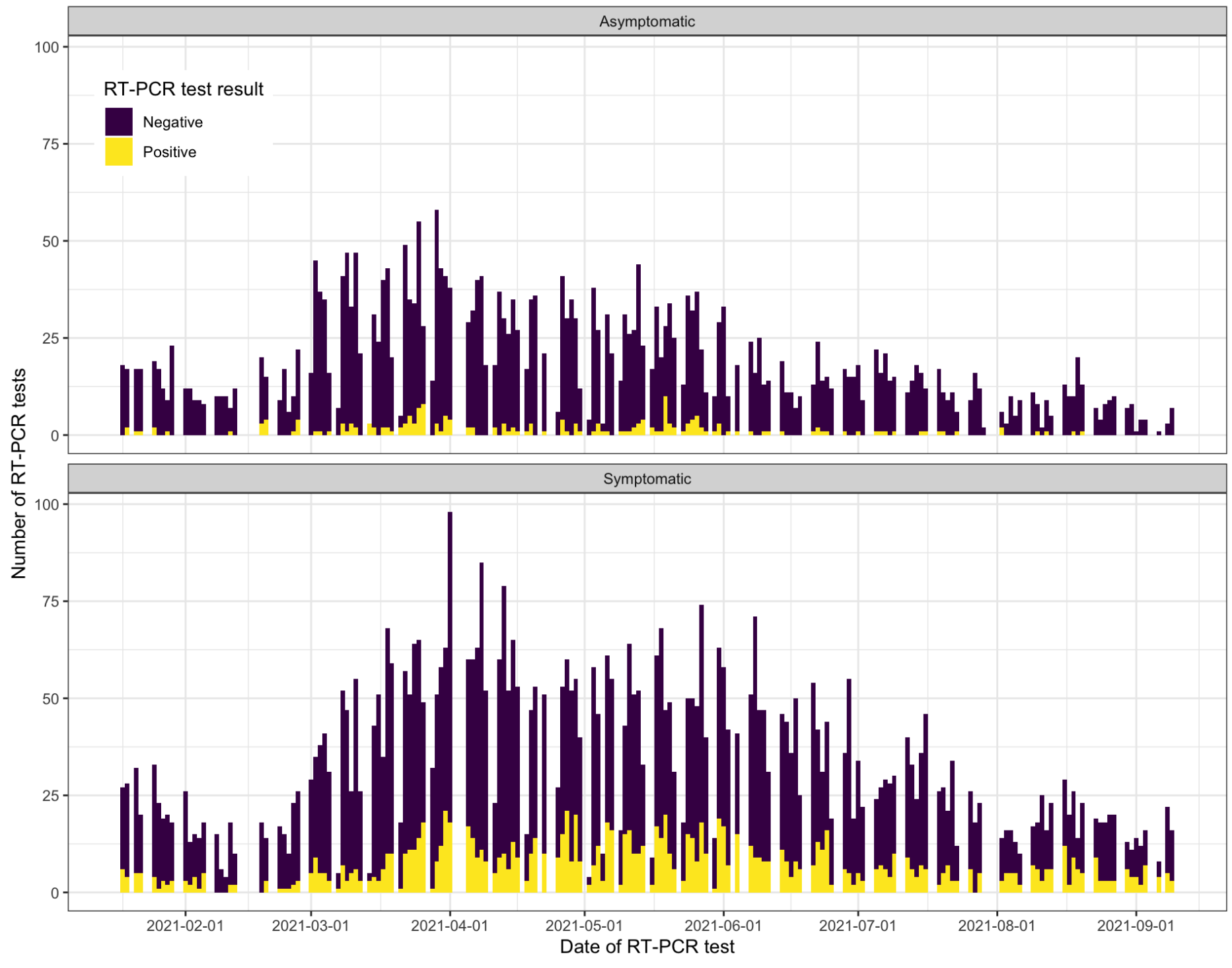


efigure3. Test positivity proportion during the study period stratified by presence of symptoms

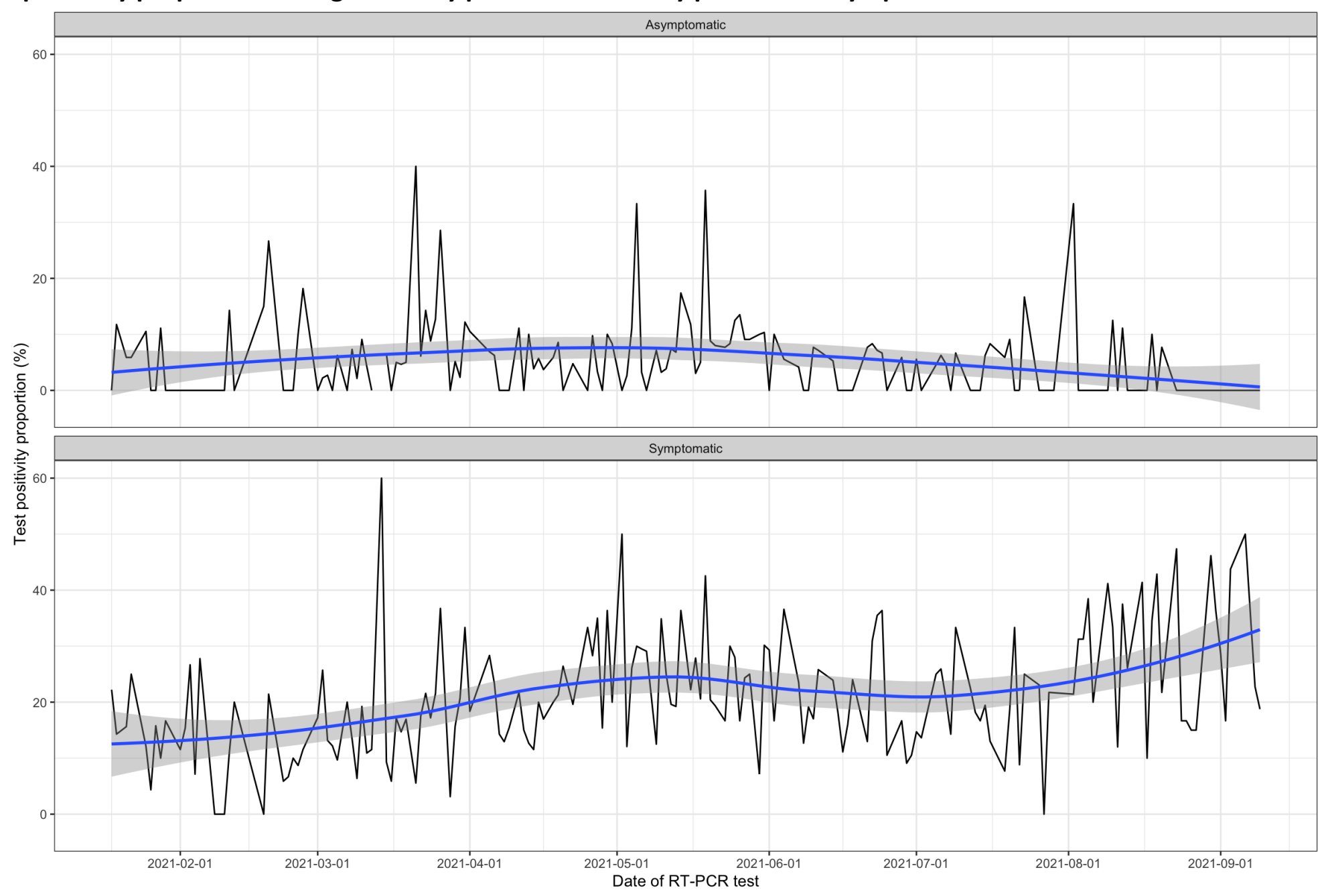

The blue line represents the smooth curve and shade area the $95 \%$ confidence intervals 
eFigure 4. First doses of AstraZeneca vaccine during the vaccination campaign in the "Complexo da Maré"

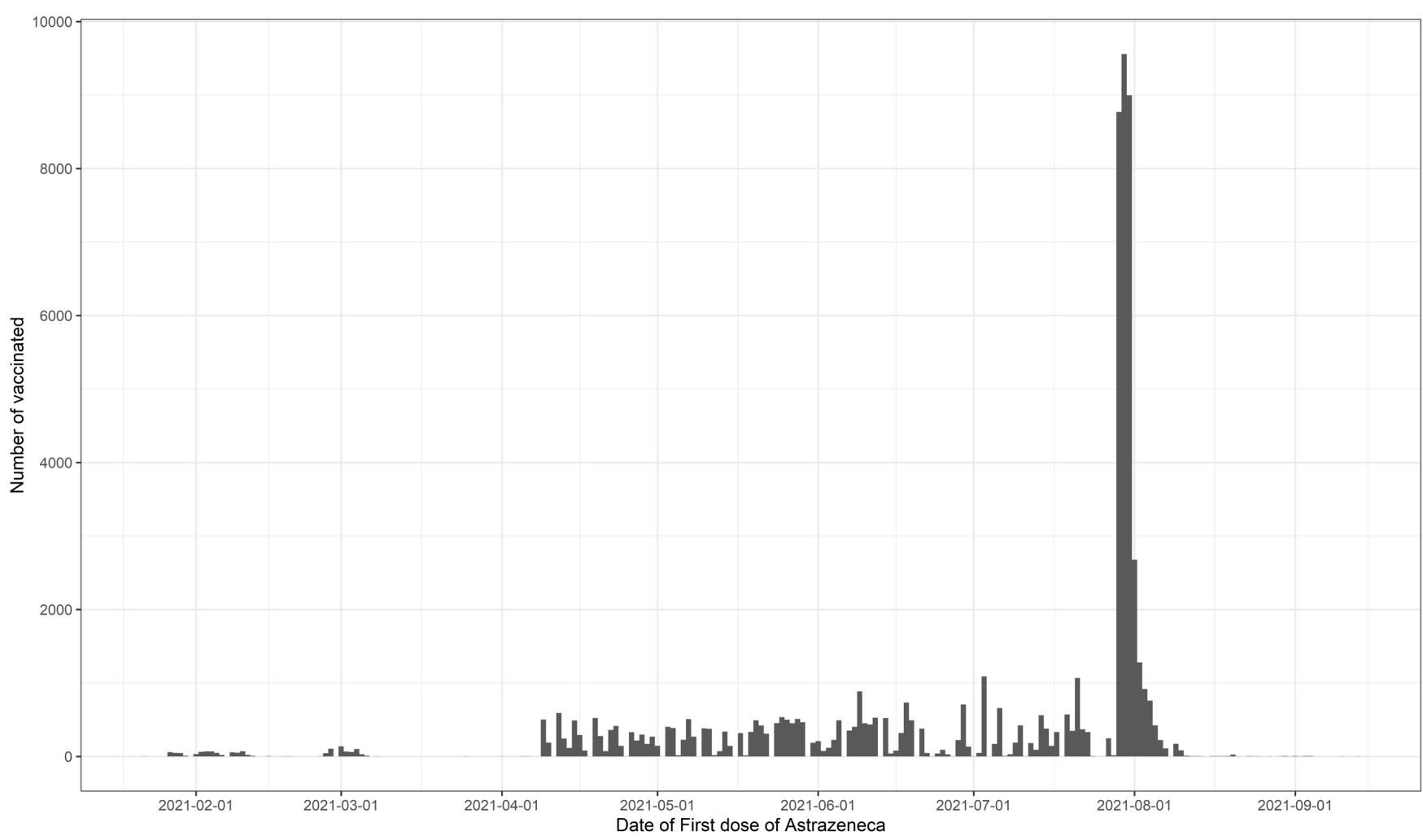


medRxiv preprint doi: https://doi.org/10.1101/2021.10.16.21265095; this version posted October 20, 2021. The copyright holder for this preprint (which was not certified by peer review) is the author/funder, who has granted medRxiv a license to display the preprint in perpetuity.

eTable 1 - Characteristics for the symptomatic cases

\begin{tabular}{|c|c|c|c|}
\hline & $\begin{array}{c}\text { Overall } \\
(n=5,890)\end{array}$ & $\begin{array}{l}\text { Test Negative } \\
(n=4679)\end{array}$ & $\begin{array}{c}\text { Test Positive } \\
(n=1211)\end{array}$ \\
\hline Age, mean \pm SD & $38.0(13)$ & $38.0(13)$ & $38.1(13)$ \\
\hline Age $\leq 35$ years & $2838(48.2)$ & $2249(48.1)$ & $589(48.6)$ \\
\hline Age $>35$ years & $3052(51.8)$ & $2430(51.9)$ & $622(51.4)$ \\
\hline \multicolumn{4}{|l|}{ Sex } \\
\hline Female & $3809(64.7)$ & $3079(65.8)$ & $730(60.3)$ \\
\hline Male & $2081(35.3)$ & $1600(34.2)$ & 481 (39.7) \\
\hline \multicolumn{4}{|l|}{ Self-reported race } \\
\hline White & $1443(24.5)$ & $1149(24.6)$ & $294(24.3)$ \\
\hline Brown & $2383(40.5)$ & $1902(40.6)$ & $481(39.7)$ \\
\hline Black & $1021(17.3)$ & $822(17.6)$ & $199(16.4)$ \\
\hline Other & $143(2.4)$ & $116(2.5)$ & $27(2.2)$ \\
\hline Missing & $900(15.3)$ & 690 (14.7) & $210(17.3)$ \\
\hline \multicolumn{4}{|l|}{ Comorbidities* } \\
\hline Cardiovascular disease & $420(7.1)$ & $350(7.5)$ & $70(5.8)$ \\
\hline Respiratory disease & $182(3.1)$ & $153(3.3)$ & $29(2.4)$ \\
\hline Imunossupressed status & $231(3.9)$ & $190(4.1)$ & $41(3.4)$ \\
\hline Liver disease & $97(1.6)$ & $76(1.6)$ & $21(1.7)$ \\
\hline Obesity & $536(9.1)$ & $450(9.6)$ & $86(7.1)$ \\
\hline Diabetes mellitus & $393(6.7)$ & $327(7.0)$ & $66(5.5)$ \\
\hline \multicolumn{4}{|l|}{ Occupation } \\
\hline Other & $5613(95.3)$ & $4437(94.8)$ & $1176(97.1)$ \\
\hline Security & $67(1.1)$ & $56(1.2)$ & $11(0.9)$ \\
\hline Healthcare worker & $210(3.6)$ & $186(4.0)$ & $24(2.0)$ \\
\hline \multicolumn{4}{|l|}{ Region of residence } \\
\hline Centre & $3164(53.7)$ & $2555(54.6)$ & $609(50.3)$ \\
\hline North & $417(7.1)$ & $324(6.9)$ & $93(7.7)$ \\
\hline South & $2309(39.2)$ & $1800(38.5)$ & $509(42.0)$ \\
\hline \multicolumn{4}{|l|}{ Vaccination status } \\
\hline \multicolumn{4}{|l|}{ Main analysis } \\
\hline Unvaccinated & $4988(84.7)$ & 3956 (84.5) & $1032(85.2)$ \\
\hline $0-13$ days after first dose & $132(2.2)$ & $102(2.2)$ & $30(2.5)$ \\
\hline 14-21 days after first dose & $111(1.9)$ & $82(1.8)$ & $29(2.4)$ \\
\hline$>21$ days after first dose & 659 (11.2) & $539(11.5)$ & $120(9.9)$ \\
\hline \multicolumn{4}{|l|}{ Sensitivity analysis } \\
\hline Unvaccinated & $4988(84.7)$ & 3956 (84.5) & $1032(85.2)$ \\
\hline 0-13 days after first dose & $132(2.2)$ & $102(2.2)$ & $30(2.5)$ \\
\hline 14-27 days after first dose & $204(3.5)$ & $156(3.3)$ & $48(4.0)$ \\
\hline 28-41 days after first dose & $182(3.1)$ & $149(3.2)$ & $33(2.7)$ \\
\hline 42-55 days after first dose & $127(2.2)$ & $111(2.4)$ & $16(1.3)$ \\
\hline$>56$ days after first dose & $257(4.4)$ & $205(4.4)$ & $52(4.3)$ \\
\hline $\begin{array}{l}\text { Time between vaccination and PCR, } \\
\text { median }[\mathrm{p} 25, \mathrm{p} 75]\end{array}$ & $36[20,60]$ & $37[20,59]$ & $32[18,61]$ \\
\hline
\end{tabular}

* 2 missing values for each comorbidity. Data as $\mathrm{N}(\%)$ unless differently reported 
medRxiv preprint doi: https://doi.org/10.1101/2021.10.16.21265095; this version posted October 20, 2021. The copyright holder for this preprint (which was not certified by peer review) is the author/funder, who has granted medRxiv a license to display the preprint in perpetuity. eTable 2. Characteristics forde available under a CC-BY-NC-ND 4.0 International license

\begin{tabular}{|c|c|c|c|}
\hline & $\begin{array}{l}\text { Overall } \\
(n=3307)\end{array}$ & $\begin{array}{l}\text { Test Negative } \\
(n=3112)\end{array}$ & $\begin{array}{c}\text { Test Positive } \\
(n=195)\end{array}$ \\
\hline Age, mean \pm SD & $42.6(15)$ & $42.6(15)$ & $42.4(15)$ \\
\hline Age $\leq 35$ years & $1161(35.1)$ & $1091(35.1)$ & $70(35.9)$ \\
\hline Age $>35$ years & $2146(64.9)$ & 2021 (64.9) & $125(64.1)$ \\
\hline \multicolumn{4}{|l|}{ Sex } \\
\hline Female & $1952(59.0)$ & 1834 (58.9) & $118(60.5)$ \\
\hline Male & $1355(41.0)$ & $1278(41.1)$ & $77(39.5)$ \\
\hline \multicolumn{4}{|l|}{ Self-reported race } \\
\hline White & $607(18.4)$ & $571(18.3)$ & $36(18.5)$ \\
\hline Brown/Pardo & $1116(33.7)$ & $1048(33.7)$ & $68(34.9)$ \\
\hline Black & $667(20.2)$ & $628(20.2)$ & $39(20.0)$ \\
\hline Other & $95(2.9)$ & $90(2.9)$ & $5(2.6)$ \\
\hline Missing & $822(24.9)$ & 775 (24.9) & $47(24.1)$ \\
\hline \multicolumn{4}{|l|}{ Comorbidities* } \\
\hline Cardiovascular disease & $254(7.7)$ & $242(7.8)$ & $12(6.2)$ \\
\hline Respiratory disease & $41(1.2)$ & $38(1.2)$ & $3(1.5)$ \\
\hline Imunossupressed status & $66(2.0)$ & $63(2.0)$ & $3(1.5)$ \\
\hline Liver disease & $23(0.7)$ & $23(0.7)$ & $0(0.0)$ \\
\hline Obesity & $159(4.8)$ & $154(4.9)$ & $5(2.6)$ \\
\hline Diabetes mellitus & $190(5.7)$ & $185(5.9)$ & $5(2.6)$ \\
\hline \multicolumn{4}{|l|}{ Occupation } \\
\hline Other & $3180(96.2)$ & $2988(96.0)$ & $192(98.5)$ \\
\hline Security & $38(1.1)$ & $37(1.2)$ & $1(0.5)$ \\
\hline Healthcare worker & $89(2.7)$ & $87(2.8)$ & $2(1.0)$ \\
\hline \multicolumn{4}{|l|}{ Region of residence } \\
\hline Centre & $1765(53.4)$ & 1664 (53.5) & $101(51.8)$ \\
\hline North & $305(9.2)$ & $288(9.3)$ & $17(8.7)$ \\
\hline South & $1237(37.4)$ & $1160(37.3)$ & $77(39.5)$ \\
\hline \multicolumn{4}{|l|}{ Vaccination status } \\
\hline \multicolumn{4}{|l|}{ Main analysis } \\
\hline Unvaccinated & $2731(82.6)$ & $2559(82.2)$ & $172(88.2)$ \\
\hline $0-13$ days after first dose & $102(3.1)$ & $96(3.1)$ & $6(3.1)$ \\
\hline 14-21 days after first dose & $72(2.2)$ & $67(2.2)$ & $5(2.6)$ \\
\hline$>21$ days after first dose & $402(12.2)$ & $390(12.5)$ & $12(6.2)$ \\
\hline \multicolumn{4}{|l|}{ Sensitivity analysis } \\
\hline Unvaccinated & $2731(82.6)$ & $2559(82.2)$ & $172(88.2)$ \\
\hline $0-13$ days after first dose & $102(3.1)$ & $96(3.1)$ & $6(3.1)$ \\
\hline 14-27 days after first dose & $135(4.1)$ & $128(4.1)$ & $7(3.6)$ \\
\hline 28-41 days after first dose & $88(2.7)$ & $87(2.8)$ & $1(0.5)$ \\
\hline 42-55 days after first dose & $72(2.2)$ & $69(2.2)$ & $3(1.5)$ \\
\hline$>56$ days after first dose & $179(5.4)$ & $173(5.6)$ & $6(3.1)$ \\
\hline $\begin{array}{l}\text { Time between vaccination and PCR, } \\
\text { median }[\mathrm{p} 25, \mathrm{p} 75]\end{array}$ & $35[18,61]$ & $35[18,61]$ & $24[13,56]$ \\
\hline
\end{tabular}

$* 1$ missing value for each comorbidity. Data as $\mathrm{N}(\%)$ unless differently reported 
medRxiv preprint doi: https://doi.org/10.1101/2021.10.16.21265095; this version posted October 20, 2021. The copyright holder for this preprint (which was not certified by peer review) is the author/funder, who has granted medRxiv a license to display the preprint in perpetuity. eTable 3 - It is made available under a CC-BY-NC-ND 4.0 International license

\begin{tabular}{|c|c|c|c|}
\hline & $\begin{array}{l}\text { Overall } \\
(n=9197)\end{array}$ & $\begin{array}{l}\text { Test Negative } \\
(n=7791)\end{array}$ & $\begin{array}{l}\text { Test Positive } \\
(n=1406)\end{array}$ \\
\hline Age, mean \pm SD & $39.6(14)$ & $39.8(14)$ & $38.7(14)$ \\
\hline Age $\leq 35$ years & 3999 (43.5) & 3340 (42.9) & 659 (46.9) \\
\hline Age $>35$ years & $5198(56.5)$ & $4451(57.1)$ & $747(53.1)$ \\
\hline \multicolumn{4}{|l|}{ Sex } \\
\hline Female & $5761(62.6)$ & $4913(63.1)$ & $848(60.3)$ \\
\hline Male & $3436(37.4)$ & 2878 (36.9) & $558(39.7)$ \\
\hline \multicolumn{4}{|l|}{ Self-reported race } \\
\hline White & $2050(22.3)$ & $1720(22.1)$ & $330(23.5)$ \\
\hline Brown & $3499(38.0)$ & 2950 (37.9) & $549(39.0)$ \\
\hline Black & $1688(18.4)$ & $1450(18.6)$ & $238(16.9)$ \\
\hline Other & $238(2.6)$ & $206(2.6)$ & $32(2.3)$ \\
\hline Missing & $1722(18.7)$ & $1465(18.8)$ & $257(18.3)$ \\
\hline \multicolumn{4}{|l|}{ Comorbidities* } \\
\hline Cardiovascular disease & $674(7.3)$ & $592(7.6)$ & $82(5.8)$ \\
\hline Respiratory disease & $223(2.4)$ & $191(2.5)$ & $32(2.3)$ \\
\hline Imunossupressed status & $297(3.2)$ & $253(3.2)$ & $44(3.1)$ \\
\hline Liver disease & $120(1.3)$ & $99(1.3)$ & $21(1.5)$ \\
\hline Obesity & $695(7.6)$ & $604(7.8)$ & $91(6.5)$ \\
\hline Diabetes mellitus & $583(6.3)$ & $512(6.6)$ & $71(5.0)$ \\
\hline \multicolumn{4}{|l|}{ Occupation } \\
\hline Other & $8793(95.6)$ & 7425 (95.3) & $1368(97.3)$ \\
\hline Security & $105(1.1)$ & $93(1.2)$ & $12(0.9)$ \\
\hline Healthcare worker & $299(3.3)$ & $273(3.5)$ & $26(1.8)$ \\
\hline \multicolumn{4}{|l|}{ Region of residence } \\
\hline Centre & $4929(53.6)$ & $4219(54.2)$ & $710(50.5)$ \\
\hline North & $722(7.9)$ & $612(7.9)$ & $110(7.8)$ \\
\hline South & $3546(38.6)$ & $2960(38.0)$ & $586(41.7)$ \\
\hline \multicolumn{4}{|l|}{ Vaccination status } \\
\hline \multicolumn{4}{|l|}{ Main analysis } \\
\hline Unvaccinated & 7719 (83.9) & $6515(83.6)$ & $1204(85.6)$ \\
\hline $0-13$ days after first dose & $234(2.5)$ & $198(2.5)$ & $36(2.6)$ \\
\hline 14-21 days after first dose & $183(2.0)$ & $149(1.9)$ & $34(2.4)$ \\
\hline$>21$ days after first dose & $1061(11.5)$ & 929 (11.9) & $132(9.4)$ \\
\hline \multicolumn{4}{|l|}{ Sensitivity analysis } \\
\hline Unvaccinated & 7719 (83.9) & 6515 (83.6) & $1204(85.6)$ \\
\hline $0-13$ days after first dose & $234(2.5)$ & $198(2.5)$ & $36(2.6)$ \\
\hline 14-27 days after first dose & $339(3.7)$ & $284(3.6)$ & 55 (3.9) \\
\hline 28-41 days after first dose & $270(2.9)$ & $236(3.0)$ & $34(2.4)$ \\
\hline 42-55 days after first dose & $199(2.2)$ & $180(2.3)$ & $19(1.4)$ \\
\hline$>56$ days after first dose & $436(4.7)$ & $378(4.9)$ & $58(4.1)$ \\
\hline $\begin{array}{l}\text { Time between vaccination and PCR, } \\
\text { median }[p 25, p 75]\end{array}$ & $36[19,60]$ & $36[20,60]$ & $32[17,60]$ \\
\hline
\end{tabular}

* 5 missing values for each comorbidity. Data as $\mathrm{N}(\%)$ unless differently reported 
medRxiv preprint doi: https://doi.org/10.1101/2021.10.16.21265095; this version posted October 20, 2021. The copyright holder for this preprint (which was not certified by peer review) is the author/funder, who has granted medRxiv a license to display the preprint in perpetuity. It is made available under a CC-BY-NC-ND 4.0 International license.

eTable 4. Vaccine effectiveness against symptomatic COVID-19 (sensitivity analysis excluding test-negatives with taste/smell symptoms)

\begin{tabular}{|c|c|c|}
\hline & \multicolumn{2}{|c|}{$\begin{array}{c}\text { Symptomatic } \\
\text { (n=4,951 tests) }\end{array}$} \\
\hline & OR (95\% Cl) & VE $(95 \% \mathrm{Cl})$ \\
\hline \multicolumn{3}{|c|}{ Adjusted by time of pandemic* } \\
\hline Unvaccinated & Reference & Reference \\
\hline $0-13$ days after first dose & $0.83(0.54,1.28)$ & $17.2 \%(-28.0,46.4)$ \\
\hline 14-21 days after first dose & $1.01(0.64,1.60)$ & $-1.2 \%(-59.8,35.9)$ \\
\hline$>21$ days after first dose & $0.53(0.41,0.70)$ & $46.5 \%(30.4,58.9)$ \\
\hline \multicolumn{3}{|l|}{ Fully adjusted^ } \\
\hline Unvaccinated & Reference & Reference \\
\hline $0-13$ days after first dose & $0.88(0.56,1.36)$ & $12.2 \%(-36.4,43.5)$ \\
\hline 14-21 days after first dose & $1.00(0.63,1.60)$ & $-0.3 \%(-59.7,37.0)$ \\
\hline$>21$ days after first dose & $0.54(0.41,0.71)$ & $46.5 \%(29.4,59.5)$ \\
\hline
\end{tabular}

* Adjusted by day of the year of RT-PCR testing (restricted cubic spline); ^ Adjusted by age (restricted cubic spline), sex, cardiovascular disease, respiratory disease, obesity, diabetes mellitus, immunosuppressed status (includes cancer), liver disease, occupation, region of residence, self-reported race, reason of testing, and day of the year of RT-PCR testing using a restricted cubic spline. 
medRxiv preprint doi: https://doi.org/10.1101/2021.10.16.21265095; this version posted October 20, 2021. The copyright holder for this preprint (which was not certified by peer review) is the author/funder, who has granted medRxiv a license to display the preprint in perpetuity. It is made available under a CC-BY-NC-ND 4.0 International license.

eTable 5. Vaccine effectiveness against asymptomatic COVID-19 (sensitivity analysis)

\begin{tabular}{|c|c|c|}
\hline & \multicolumn{2}{|c|}{$\begin{array}{c}\text { Symptomatic } \\
\text { ( } n=4,951 \text { tests) }\end{array}$} \\
\hline & OR $(95 \% \mathrm{Cl})$ & VE $(95 \% \mathrm{Cl})$ \\
\hline \multicolumn{3}{|l|}{ Adjusted by time of pandemic* } \\
\hline Unvaccinated & Reference & Reference \\
\hline $0-13$ days after first dose & $0.97(0.41,2.28)$ & $3.3 \%(-127.8,59.0)$ \\
\hline 14-21 days after first dose & $1.30(0.50,3.37)$ & $-30.1 \%(-237.5,49.8)$ \\
\hline$>21$ days after first dose & $0.62(0.31,1.23)$ & $38.0 \%(-22.6,68.7)$ \\
\hline \multicolumn{3}{|l|}{ Fully adjusted^ } \\
\hline Unvaccinated & Reference & Reference \\
\hline 0-13 days after first dose & $1.01(0.42,2.42)$ & $-1.1 \%(-142.3,57.8)$ \\
\hline 14-21 days after first dose & $1.35(0.51,3.55)$ & $-35.0 \%(-255.5,48.7)$ \\
\hline$>21$ days after first dose & $0.70(0.34,1.44)$ & $29.8 \%(-44.2,65.8)$ \\
\hline
\end{tabular}

* Adjusted by day of the year of RT-PCR testing (restricted cubic spline); ${ }^{\wedge}$ Adjusted by age (restricted cubic spline), sex, cardiovascular disease, respiratory disease, obesity, diabetes mellitus, immunosuppressed status (includes cancer), liver disease, occupation, region of residence, self-reported race, reason of testing, and day of the year of RT-PCR testing using a restricted cubic spline. 